Przegląd Badań Edukacyjnych Educational Studies Review

ISSN 1895-4308

nr 28 (1/2019), s. 149-160

METAANALIZY

BADAŃ

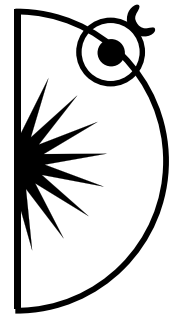

Leszek Waga

ORCID: 0000-0002-2159-5950

University of Opole; e-mail: Iwaga@uni.opole.pl

\title{
Typologies of the Understanding of the Experience Notion in Pedagogy
}

http://dx.doi.org/10.12775/PBE.2019.008

\begin{abstract}
The aim of this paper is to present possible typologies of experience and to point out the need to allow for the multidimensionality of experience categories in pedagogical research. Since experience is primarily a philosophical concept, the first section presents a generally acceptable definition of experience. The second section refers to the main philosophical, epistemological and methodological typologies of experience. The last of the typologies which may be of particular use in pedagogy has been discussed in the third section. It describes experience as an activity, its production (result), and a way of perceiving something. This typology organises the types of understanding experiences in pedagogical literature, considering all the elements of the educational relation. Reflections on the understanding of experience in pedagogy lead to the conclusion that the discipline cannot ignore different typologies of experience or the multidimensional contexts of its occurrence and experience itself turns out to be the category that integrates different levels of pedagogical knowledge. At the same time, it was confirmed that one may not analyse ontological, epistemological and methodological concepts or categories in pedagogy in isolation from philosophical considerations. Otherwise, one may be exposed to ignorance or unjustified simplifications.
\end{abstract}

Key words: experience, observation, experiment, empiricism, epistemology of pedagogy. 


\section{Introduction}

Pedagogy - as a scientific discipline - is related to the humanities and social sciences (Kubinowski, 2006; Kunowski, 2000; Lewowicki, 1997; Nowak, 2000, 2012, 2016). Humanism is categorised as a real (inductive) science (Kamiński, 1992), but it is characterised by the empirical nature of scientific cognition which 'cannot do without experience' (Grobler, 2006, p. 23). Social sciences, in turn, consider a man as a creature living in a particular community, refer to specific social conditions that are the subject matter of human experience (Nowak, 2000). Therefore, experience is the primary category (concept) in pedagogy.

The category has not been comprehensively covered in the most recent editions of The Encyclopaedia of Pedagogy (Encyklopedia Pedagogiczna, Pomykało, 1993) or The Pedagogical Encyclopaedia of the 21 $1^{\text {st }}$ century (Encyklopedia Pedagogiczna XXI wieku, Pilch, 2003-2007). Even if any articles attempt to discuss it, they are usually limited to an analysis of a certain aspect of it. The lack of one and systematic study of the importance of experience in pedagogy may be a consequence of the complexity of this problem that entails many different ontological, epistemological and methodological positions. Furthermore, the very concept of experience is ambiguous. The ambiguity is not only intensified by the presence of different scientific approaches, but also of numerous colloquial meanings (Dębowski, 2001; Krąpiec, 1976, 2001; Piecuch, 2004; Piłat, 2006; Stępień, 1974, 1997; Stróżewski, 1988; Wolsza, 1999, 2011).

The primary purpose of this article is to present possible typologies of experience and to highlight the need to allow for the multidimensionality of experience categories in pedagogical research, in both substantive and metasubstantive considerations. The foregoing purpose will be accomplished by means of firstly determining a definition of experience, generally acceptable in philosophy, and the discussions related to it, followed by a brief outline of the contexts in which one may discuss experience in philosophy. Further on, based on philosophical considerations, a typology of experience as a pedagogical category can be suggested. All the analyses will be supplemented with conclusions and postulates that may be applied in educational research.

The author will apply the method of a logical analysis and reconstruction of research activities in pedagogy, and their codification, due to the role of the multidimensionally interpreted experience (please refer to Kamiński, 1992). The foregoing considerations will be carried out with the use of the source literature analysis and criticism method. Its application will enable extraction of the necessary epistemology and pedagogy methodology content. The foregoing 
method enables identification of the line of development of various positions within the problem discussed, extraction of the differences between them, description of the formation of their impact on theory and practice, and it inspires the formulation of further research questions alongside the research carried out (Goriszowski, 2006).

In search for a plane of dialogue between different ontological, epistemological and methodological positions, while attempting to overcome the problem of incommensurability in pedagogical research (please refer to Śleziński, 2018), the author will adopt the concept of internal realism held by Hilary Putnam (1926-2016), presented as the most advanced one in the book by Adam Grobler (2006); in the field of pedagogy, it appears to be exemplified by the concept of general pedagogy with the lower case ' $g$ ' [pedagogika ogólna with the lower case 'o'], developed by Andrzej Pluta (1997).

The analyses will be carried out based on a small fragment of the research into the role of experience in the creation of pedagogical knowledge which the author of this paper conducted in the course of his $\mathrm{PhD}$ seminar. The research source literature comprised more than a thousand publications in the field of pedagogy, in particular, general pedagogy, as well as epistemology and methodology of pedagogy (Waga, 2016).

\section{Definition of experience}

The definition of experience that is relatively commonly applied in philosophy defines it as immediate and sensory cognition of something individual (Kamiński, 1992; Stępień, 1974, 1997, 2001). Accepting the foregoing definition, one should next review the concepts of: cognition (which also covers the problem of consciousness and preconscious elements in cognition), immediacy, sense, and the individual object. Those concepts have been covered in numerous monographs and papers (Dębowski, 1987a, 1987b, 1999, 2000, 2001; Woleński 2007) which indicate that the problem of experience is raised in nearly all epistemological disputes.

Resolutions of those disputes greatly affect the understanding of experience. For instance: if, apart from the primary (i.e. perceptive) and secondary (i.e. both reproductive, including reminding, and creative, in the form of imagination or fantasy) sense, i.e. apart from the external sense, there is also nonsensory (categorical, or imaginative) perception (Blaustein, 1993; Chudy, 1981; Descartes, 2001, 2002; Husserl, 1975, 2009; Twardowski, 1965), intuition may be perceived as a kind of experience in certain concepts of understanding of an 
individual object and the ability to cognise it (please refer to Czeżowski, 1958; Dębowski, 2001; Wolsza, 1999).

\section{Experience as a philosophical category}

The most important approaches to the understanding of experience in philosophy have been summarised by Kazimierz Wolsza. First of all, he identified three variants of the empirical approach: Aristotelian-Thomistic, modern empirical, and the one developed by Immanuel Kant. They all describe man as the subject of experience, equipped with a sensory and mental cognitive apparatus, but they differ in the relation between sensory action and mental action: the AristotelianThomistic variant emphasises the synthesis of sensory and mental cognition; the modern empirical variant minimises mental activity while emphasising sensory perception, and the variant developed by Kant stresses the impact of mental activity on the constitution of the very subject of experience (Wolsza, 1999).

Secondly, K. Wolsza referred to the phenomenological approach which recognises both sensory data, one-off and actual states of things, and any direct data, being permanent and perfect states, as the subject of experience. Due to phenomenology overcoming the empirical model, experience and experiencing were considered types of experience (Tatarkiewicz 2002; Wolsza, 1999), although philosophers do not always accept the expansion of the meaning of the concept of experience with the phenomenological understanding (Woleński, 2007).

Thirdly, the so-called hermeneutical approach was distinguished. As far as the phenomenological approach gradually eliminates what is not directly provided from the source, hermeneutics allows for the entire context of history and language associated with tradition. The aim of phenomenology is to use experience in order to obtain absolute knowledge that is beyond doubt; on the other hand, hermeneutics aims to obtain knowledge depending on the context, by means of eliminating conclusions drawn from successive experiences (Wolsza, 1999; please refer to Bronk, 1998).

In epistemological reflection, the multidimensional nature of experience is manifested in the multiplicity of its varieties. Antoni Bazyli Stępien (2001) distinguished: $1^{\circ}$ external sensory observation; $2^{\circ}$ internal sensory observation; $3^{\circ}$ internal observation; $4^{\circ}$ external psyche observation; $5^{\circ}$ reminding; $6^{\circ}$ quasiobservation as aesthetic perception of what is presented visually; $7^{\circ}$ perception in the imagination, understood as a type of aesthetic perception characterised by imaginative perception associated with, for example, perception of a literary work; 
$8^{\circ}$ perception (intuition) of values; $9^{\circ}$ moral experience, or experience of morality of something; $10^{\circ}$ religious experience; $11^{\circ}$ experience and experiencing.

Observation and experiment are the subjects of experience. 'Observation is a careful experience, with a specific purpose. An experiment is an experience (observation) of something caused by the observer in a planned situation. Thus, observation and the experiment pursue a certain goal, they seek answers to certain questions' (Stępień, 2001, p. 119). So interpreted experience is one of the instruments of scientific cognition; thus, the problem of experience falls within the scope of the methodology of science (Hajduk, 2005).

Given the foregoing analyses, one may further indicate another, triple way of understanding experience. Experience - as Kazimierz Twardowski (1866-1938) claimed - is either $1^{\circ}$ an act of cognition or $2^{\circ}$ its product, or result, referred to as information and knowledge (Twardowski, 1997; please refer to Kamiński 1992). It is also $3^{\circ}$ an instrumentally understood manner (method) of cognition. The distinction between the third type of the understanding of experience from the other two, in particular from experience-product, is - according to Dorota Wolska (2012) - one of the key issues of cultural studies, interpreted as humanistic knowledge of the culture. In the third sense, an experience is any conscious (cognition-accompanying) act, together with the corresponding result, which in itself does not provide any new knowledge, but which enables or facilitates acquisition of information, improves and consolidates the acquired knowledge, and enables its application (Stępień, 2001).

It can be assumed that on the basis of these three approaches to the concept of experience, three separate directions of empiricism were formed, respectively: genetic, theoretical and methodological. The first of them is in dispute with nativism, the second one - with rationalism, and the third (like the former one) - with apriorism (Sokołowski, 2002; Stępień, 2001; Woleński, 2007). It also appears that each of the three ways of understanding the concept of experience is related to the three primary areas of human rational activity, respectively: experience as an act of cognising or experiencing - with $\pi \rho \tilde{\alpha} \xi 1 \varsigma$ (praxis); experience as a product and result of a cognitive act - with $\theta \varepsilon \omega p i ́ \alpha$ (theoria); and experi-

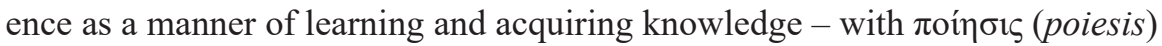
(please refer to Krąpiec, 1990; Nowak, 2000; Stępkowski, 2007, 2008).

\section{The concept of experience in pedagogy}

Decisions of a philosophical nature do have an impact on the development of pedagogical research. Referring to the empirical, phenomenological and herme- 
neutical approaches to experience, one may assume that the latter two are the most interesting ones to educational researchers. Phenomenological and hermeneutical positions play an inspiring role not only in the field of epistemological concepts, but also in methodological ones, in particular in the humanities and social sciences, as this is where ontological, theoretical and methodological issues concentrate (Ablewicz, 2010). Modern philosophy undertakes the same '[continuous] effort to report on the entire human experience' (Folkierska, 1992, p. 308); consequently, 'due to philosophy [...], it is possible to go beyond the 'locality' of the observation, or, in better words, a chance to realise the multidimensionality of the experience and co-created educational situations and theories discovered...' (Rotkiewicz, 1995, p. 49).

The epistemological typology developed by A.B. Stępień plays an undeniably important role in the systematisation of the concepts of experience (in didactics as well as many other pedagogical subdisciplines). Observations, reminders, intuition or experiences of all the participants in education are one of the primary sources of educational research.

Finally, it may be useful to apply the three-way understanding of experience which differentiates the act, its product and the instrumentally interpreted manner of cognition from one another. Although the distinction is not clearly identified in the pedagogical literature, it is possible to be reconstructed based on the writings of numerous pedagogues, inter alia, Zofia Sękowska (1953), Stefan Wołoszyn (1954), Wincenty Okoń (2007), Andrea Folkierska (1995), or Teresa Hejnicka-Bezwińska $(1989,2008)$. For example, T. HejnickaBezwińska noted that 'pedagogy finds the following meanings important: cognition interpreted as a conscious act (...), and cognition interpreted as a result of cognition (...). The very act of cognition and its results may be the subject matter of a separate cognitive act, and that is how epistemology defines its domain (...)' (2008, p. 290). If, according to the foregoing classical definition of experience, it is a kind of cognition (in this definition, the concept of cognition serves as genus proximum), then - by analogy to cognition - it may be deemed reasonable to undertake attempts to seek a three-way understanding of experience as: an act, a product, and an instrumentally interpreted manner of cognition.

Experience as an act (an act of cognition, learning, experiencing) may be attributed to both students and teachers being the subjects of that experience and, at the same time, the subjects of the educational relation. In the functional aspect, the researcher into the educational reality is also a subject of experience. Allowing for all the elements of the educational relation, one may also refer to 
the educational environment (the subject of the experience) as a space in which this experience takes place.

Experience - as a product of an act of cognition and experiencing - may also be attributed to the student, to the teacher, and to the researcher into the educational reality. In an analogical meaning, any educational institutions, or the very academic pedagogy (having some distinctive achievements: experience with scientific and practical activities) are the subjects of experience. Experience - product also means the philosophical and cultural traditions (as the experience of social groups or of the entire society). Finally, it may be knowledge perceived as an element of social practice.

Referring to the levels of methodological reflection in pedagogy, distinguished by Stanisław Palka (2006), experience as a way of understanding and acquiring information may be perceived in the light of pedagogical methodology, methodology of pedagogical research, and methods of pedagogical research. In this case, the following terms become relevant: experience, observation, experiment, practice, empiricism, experimentation, and all the other concepts remaining in ontological, epistemological and methodological dispute in them.

For instance, when investigating the methodological problem of experience in the research into education, one might note it is a different role and a different status of the empirical data in quantitative and qualitative research strategies, in theoretical (exploratory and verification) as well practical (diagnostic, evaluative and operating) types of research, or, finally, in various research schemes (experimental and correlational, ethnographic, historical and case studies) providing a nomothetic or idiographic explanation of reality, respectively (please refer to Rubacha, 2008).

It appears that the typology of experience, distinguishing its understanding as an act, a product, and a manner of cognition, along with semantic references to other concepts (such as practice, experience, intuition, knowledge, routine...) arranges into order the multiplicity of contexts in which this category is present in pedagogical analyses.

This typology may be of particular importance in educational research as, apart from the obvious philosophical foundations, it has a characteristic pedagogical value, allowing for the structure of the educational relation. Given the multiplicity of contexts in which experience be may defined, the problem expressed in the following question may be interesting to researchers: to what extent does the holistic approach to the discussed category ensure the integrity of knowledge developed in pedagogy, and does the absence of a multidimensional approach to experience and its different meanings not contribute to reductionism in the research? 


\section{Conclusions and postulates}

Reflections on the understanding of experience in pedagogy lead to the conclusion that the discipline cannot ignore different typologies of experience or the multidimensional contexts of its occurrence. It does not only lie in the field of empirical or experimental pedagogy interests, but it should also be considered in normative and theoretical pedagogy analyses (following S. Kunowski's terminology). It should not be interpreted empirically only; phenomenological and hermeneutic approaches to it should be allowed for, too. Finally, it would be right to acknowledge its triple dimension as an act, a product, and a manner of cognition. It seems that generality must mean openness. In this light, experience (understood multidimensionally in its numerous aspects) turns out to be the category that integrates various levels of pedagogical knowledge.

The foregoing analyses confirmed that one may not analyse ontological, epistemological and methodological concepts or categories in pedagogy in isolation from philosophical considerations. Otherwise, one may be exposed to ignorance or unjustified simplifications. In a sense, a pedagogue, as a representative of social sciences, must be a philosopher. That turn towards philosophy does not result from the practical nature of pedagogy, or from the need to determine the goals of educational activities or pedagogical standards, as pointed out by some authors postulating references to philosophical considerations in pedagogy. In the case of experience-related considerations, that turn is primarily determined by formal arguments. Above all, experience is a philosophical category. Even if one may refer to the specifics of the understanding of experience in the works of specific pedagogues, or in pedagogy as a science, it is difficult to separate this understanding from philosophical approaches.

\section{References}

Ablewicz, K. (2010). Hermeneutyka i fenomenologia a pedagogika. In: S. Palka (ed.), Podstawy metodologii badań w pedagogice (pp. 103-123). Gdańsk: Gdańskie Wydawnictwo Psychologiczne.

Blaustein, L. (1993). O naoczności jako właściwości niektórych przedstawień. In: J. J. Jadacki, B. Markiewicz (eds.), „...A Mądrości zło nie przemoże”. Wybór tekstów (pp. 44-58). Warszawa: Polskie Towarzystwo Filozoficzne.

Bronk, A. (1998). Zrozumieć świat wspótczesny. Lublin: Towarzystwo Naukowe Katolickiego Uniwersytetu Lubelskiego. 
Chudy, W. (1981). Zagadnienie naoczności aktów poznawczych. Roczniki Filozoficzne, 1, pp. 164-232.

Czeżowski, T. (1958). Zagadnienie istnienia świata w świetle przemian metodologicznych. In: T. Czeżowski (ed.), Odczyty filozoficzne (pp. 34-43). Toruń: Towarzystwo Naukowe w Toruniu.

Descartes, R. (2001). Medytacje o pierwszej filozofii. Zarzuty uczonych mężów i odpowiedziami autora. Rozmowa z Burmanem. Kęty: Wydawnictwo ANTYK - Marek Derewiecki.

Descartes, R. (2002). Reguty kierowania umystem. Poszukiwanie prawdy poprzez światto naturalne. Kęty: Wydawnictwo ANTYK - Marek Derewiecki.

Dębowski, J. (1987a). Główne pojęcia bezzałożeniowości. Studia Filozoficzne, 2, pp. 3-19.

Dębowski, J. (1987b). Idea bezzałożeniowości. Geneza i konkretyzacje. Lublin: Wydawnictwo Uniwersytetu Marii Curie-Skłodowskiej.

Dębowski, J. (1999). Bezpośredniość poznania. Spory-dyskusje - wyniki. Lublin: Wydawnictwo Uniwersytetu Marii Curie-Skłodowskiej.

Dębowski, J. (2000). Prezentacjonistyczna teoria poznania i jej uzasadnienie. In: J. Dębowski, M. Hetmański (eds.), Poznanie, człowiek, wartości (pp. 201-211). Lublin: Wydawnictwo Uniwersytetu Marii Curie-Skłodowskiej.

Dębowski, J. (2001). Świadomość. Poznanie. Naoczność poznania. Lublin: Wydawnictwo Uniwersytetu Marii Curie-Skłodowskiej.

Folkierska, A. (1992). Filozofia w kształceniu nauczycieli. In: J. Rutkowiak (ed.), Pytanie, dialog, wychowanie (pp. 295-315). Warszawa: Wydawnictwo Naukowe PWN.

Folkierska, A. (1995). Kształcąca funkcja pytania. Perspektywa hermeneutyczna. In: J. Rutkowiak (ed.), Odmiany myślenia o edukacji (pp. 155-176). Kraków: Oficyna Wydawnicza „Impuls”.

Goriszowski, W. (2006). Podstawy metodologiczne badań pedagogicznych. Warszawa: Wydawnictwo Wyższej Szkoły Pedagogicznej TWP.

Grobler, A. (2006). Metodologia nauk Kraków: Wydawnictwo Aureus - Wydawnictwo Znak.

Hajduk, Z. (2005). Ogólna metodologia nauk. Lublin: Wydawnictwo KUL.

Hejnicka-Bezwińska, T. (1989). W poszukiwaniu tożsamości pedagogiki. Świadomość teoretyczno-metodologiczna współczesnej pedagogiki polskiej (geneza i stan). Bydgoszcz: Wydawnictwo Uczelniane WSP w Bydgoszczy.

Hejnicka-Bezwińska, T. (2008). Pedagogika ogólna. Warszawa: Wydawnictwa Akademickie i Profesjonalne. 
Husserl, E. (1975). Idee czystej fenomenologii i fenomenologicznej filozofii. Księga Pierwsza, Warszawa: Państwowe Wydawnictwo Naukowe.

Husserl, E. (2009). Medytacje kartezjańskie. Wprowadzenie do fenomenologii, Warszawa: Wydawnictwo IFiS PAN.

Kamiński, S. (1992). Nauka i metoda. Pojęcie nauki i klasyfikacja nauk. Lublin: Towarzystwo Naukowe Katolickiego Uniwersytetu Lubelskiego.

Krąpiec, M. A. (1976). Doświadczenie i metafizyka. Roczniki Filozoficzne, no. 1, pp. 5-16.

Krąpiec, M. A. (1990). Prawda - dobro - piękno jako wartości humanistyczne. In: B. Suchodolski (ed.), Alternatywna pedagogika humanistyczna. Konferencja w Jabłonnie k. Warszawy $w$ dniach 29 listopada - 1 grudnia 1984 (pp. 41-61). Wrocław-Warszawa-Kraków: Zakład Narodowy im. Ossolińskich, Wydawnictwo Polskiej Akademii Nauk.

Krąpiec, M. A. (2001). Doświadczenie. In: A. Maryniarczyk (ed.), Powszechna Encyklopedia Filozofii, vol. 2 (pp. 673-676). Lublin: Polskie Towarzystwo Tomasza z Akwinu.

Kubinowski, D. (2006). Pedagogiczne myślenie humanistyczne jako kategoria metodologiczna. In: D. Kubinowski, M. Nowak (eds.), Metodologia pedagogiki zorientowanej humanistycznie (pp. 171-180). Kraków: Polskie Towarzystwo Pedagogiczne, Oficyna Wydawnicza „Impuls”.

Kunowski, S. (2000). Podstawy wspótczesnej pedagogiki. Warszawa: Wydawnictwo Salezjańskie.

Lewowicki, T. (1997). Humanistyka i pedagogika (związki oczywiste i osobliwe). In: A. Pluta (ed.), Pedagogika ogólna a filozofia nauki. Wybrane problemy poznawcze i konteksty dydaktyczne (pp. 15-22). Częstochowa: Wydawnictwo Wyższej Szkoły Pedagogicznej w Częstochowie.

Nowak, M. (2000). Podstawy pedagogiki otwartej. Ujęcie dynamiczne w inspiracji chrześcijańskiej. Lublin: Redakcja Wydawnictw Katolickiego Uniwersytetu Lubelskiego.

Nowak, M. (2012). Pedagogiczny profil nauk o wychowaniu. Studium z odniesieniami do pedagogiki pielegniarstwa. Lublin: Wydawnictwo KUL.

Nowak, M. (2016). O pedagogikę bardziej zorientowaną na nauki humanistyczne czy na nauki społeczne? Metodologia nauk humanistycznych i społecznych w pedagogice. In: F. Szlosek (ed.), Badanie - dojrzewanie - rozwój (na drodze do doktoratu). Metodologia nauk społecznych a metodologia badań pedagogicznych (pp. 65-78). Warszawa-Radom: Instytut Pedagogiki Akademii Pedagogiki Specjalnej im. M. Grzegorzewskiej w Warszawie, Instytut Technologii Eksploatacji - PIB w Radomiu.

Okoń, W. (2007). Nowy słownik pedagogiczny. Warszawa: Wydawnictwo Akademickie „Żak”. 
Palka, S. (2006). Metodologia. Badania. Praktyka pedagogiczna. Gdańsk: Gdańskie Wydawnictwo Psychologiczne.

Piecuch, J. (2004). Doświadczenie Boga. Propozycja Bernharda Weltego na tle sporu o pojęcie doświadczenia fenomenologicznego. Opole: Redakcja Wydawnictw Wydziału Teologicznego Uniwersytetu Opolskiego.

Pilch, T. (ed.). (2003-2007). Encyklopedia pedagogiczna XXI wieku, vol. 1-7, Suplement. Warszawa: Wydawnictwo Akademickie „Żak”.

Piłat, R. (2006). Doświadczenie i pojęcie. Studia z fenomenologii i filozofii umysłu. Warszawa: Wydawnictwo Instytutu Filozofii i Socjologii PAN.

Pluta, A. (1997). Pedagogika ogólna przez małe „„”. Między modernizmem a postmodernizmem. In: A. Pluta (ed.), Pedagogika ogólna a filozofia nauki. Wybrane problemy poznawcze i konteksty dydaktyczne (pp. 81-93). Częstochowa: Wydawnictwo Wyższej Szkoły Pedagogicznej w Częstochowie.

Pomykało, W. (ed.). (1993). Encyklopedia Pedagogiczna. Warszawa: Fundacja INNOWACJA.

Rotkiewicz, H. (1995). O obecności filozofii w edukacji nauczycielskiej. In: H. Kwiatkowska, T. Lewowicki (eds.). Z zagadnień pedeutologii i ksztatcenia nauczycieli (pp. 45-56). Warszawa: Komitet Nauk Pedagogicznych PAN.

Rubacha, K. (2008). Metodologia badań nad edukacją. Warszawa: Wydawnictwa Akademickie i Profesjonalne.

Sękowska, Z. (1953). Źródła pedagogiki. Roczniki Humanistyczne, 3, pp. 101-123.

Sokołowski, W. (2002). Empiryzm. In: A. Maryniarczyk (ed.), Powszechna Encyklopedia Filozofii, vol. 3 (pp. 142-147). Lublin: Polskie Towarzystwo Tomasza z Akwinu.

Stępkowski, D. (2007). (R)ewolucja prakseologiczna w myśleniu i działaniu pedagogicznym według Dietricha Bennera. Seminare. Poszukiwania Naukowe, 24, pp. 419-438.

Stępkowski, D. (2008). Praxis w koncepcji pedagogiki Dietricha Bennera. Kwartalnik Pedagogiczny, 3(209), pp. 19-58.

Stępień, A. B. (1974). Rola doświadczenia w punkcie wyjścia metafizyki. Zeszyty Naukowe $K U L, 4$, pp. 29-37.

Stępień, A. B. (1997). Doświadczenie. In: J. Herbut (ed.), Leksykon Filozofii Klasycznej (pp. 119-120). Lublin: Towarzystwo Naukowe Katolickiego Uniwersytetu Lubelskiego.

Stępień A. B., (2001). Wstęp do filozofii. Lublin: Towarzystwo Naukowe Katolickiego Uniwersytetu Lubelskiego.

Stróżewski, W. (1988). Doświadczenie i interpretacja. In: W. Stróżewski (ed.), Servo Veritatis. Materiały sesji naukowej poświęconej myśli Karola Wojtyly - Jana Pawła II. 
Uniwersytet Jagielloński, Kraków 16-17 listopada 1984 (pp. 261-281). Kraków-Warszawa: Uniwersytet Jagielloński, Państwowe Wydawnictwo Naukowe.

Śleziński, K. (2018). Uwagi o niewspółmierności w badaniach pedagogicznych. Przegląd Badań Edukacyjnych, 1(26), pp. 159-172, DOI: http://dx.doi.org/10.12775/ PBE.2018.009.

Tatarkiewicz, W. (2002). Historia filozofii, vol. 3: Filozofia XIX wieku i współczesna. Warszawa: Wydawnictwo Naukowe PWN.

Twardowski, K. (1965). Wyobrażenia i pojęcia. In: K. Twardowski (ed.). Wybrane pisma filozoficzne (pp. 114-197). Warszawa: Państwowe Wydawnictwo Naukowe.

Twardowski, K. (1997). O czynnościach i wytworach. Kilka uwag z pogranicza psychologii, gramatyki i logiki. In: T. Rzepa (ed.), Psychologia w szkole lwowsko-warszawskiej. Twardowski. Witwicki. Baley. Błachowski. Kreutz. Lewicki. Tomaszewski (pp. 109-141). Warszawa: Wydawnictwo Naukowe PWN.

Waga, L. (2016). Rola doświadczenia w tworzeniu wiedzy pedagogicznej. Lublin: mps. KUL.

Woleński, J. (2007). Epistemologia. Poznanie. Prawda. Wiedza. Realizm. Warszawa: Wydawnictwo Naukowe PWN.

Wolska, D. (2012). Odzyskać doświadczenie. Sporny temat humanistyki współczesnej. Kraków: Towarzystwo Autorów i Wydawców Prac Naukowych UNIVERSITAS.

Wolsza, K. (1999). Rola doświadczenia transcendentalnego w poznaniu filozoficznym. Opole: Wydział Teologiczny Uniwersytetu Opolskiego.

Wolsza, K. (2011). Zarys teorii podstawowego doświadczenia filozoficznego. In: K. Wolsza (ed.), Religijne wymiary doświadczenia i myślenia (pp. 11-27). Opole: Wydawnictwo i Drukarnia Świętego Krzyża w Opolu.

Wołoszyn, S. (1954). O metodyce poznawania i uogólniania doświadczenia pedagogicznego. Życie Szkoty, 2, pp. 65-75.

Wołoszyn, S. (1995). Pedagogika ogólna czy system nauk pedagogicznych? Mechanizmy dyferencjacji i reintegracji. In: T. Hejnicka-Bezwińska (ed.), Pedagogika ogólna. Tradycja - teraźniejszość - nowe wyzwania (materiały pokonferencyjne) (pp. 47-54). Bydgoszcz: Wydawnictwo Uczelniane Wyższej Szkoły Pedagogicznej w Bydgoszczy. 